\title{
PUbLIC CONTRACTS BY NEGOTIATED PROCEDURE IN CASES OF URGENCY - A NEW INTERPRETATION OF THE LEGAL BASIS IN LIGHT OF EXPERIENCES WITH ORGANIZATION OF THE 2012 EUROPEAN FOOTBALL CHAMPIONSHIPS
}

\author{
KRZYSZTOF HORUBSKI**
}

\section{INTRODUCTION}

The public procurement market undoubtedly constitutes a part of the European Union internal market, hence it is subject to basic rights of commercial freedom and competition rules. While awarding public contracts, i.e. in a situation of acquisition of goods, services or construction works by public entities which are considered state actors in a broad sense, it is essential to adhere to legal provisions on the free movement of goods, persons and capital $^{1}$ (Articles 26-37, 45-66 Treaty on the Functioning of the European Union $^{2}$ - TFEU). When preparing and conducting public procurement procedures the ordering party is obliged to ensure effectiveness of the rules of competition ${ }^{3}$ (Articles 101-109 TFEU). Awarding public procurement contracts in compliance with the requirements of secondary European Union law subordinates such market activities to the rules of equality, fair competition and transparency (see point 2 of the Preamble to Directive 2004/18/EC ${ }^{4}$ ). However, its contents contain provisions allowing for derogations from these rules justified by principles of protection of the public interest which by their nature are different from the aspirations guiding the development of the internal market. Such regulation is provided for in Article

DOI: $10.2478 /$ wrlae-2013-0046

* PhD, Assistant Profesor; Department of Public Economic Law; Faculty of Law, Administration and Economics; Wroclaw University; k.horubski@prawo.uni.wroc.pl

${ }^{1}$ See A Sołtysińska, Zamówienia publiczne w Unii Europejskiej (Zakamycze 2004) 145-146.

2 The Treaty on the Functioning of the European Union [2010] OJ L 83/47.

${ }^{3}$ Sołtysińska (n 1) 157-162. See also M Szydło, 'Udzielanie zamówienia publicznego jako pomoc państwa w rozumieniu art. 87 ust. 1 Traktatu ustanawiającego Wspólnotę Europejską' (2007) 2 Kwartalnik Prawa Prywatnego 354-398.

${ }^{4}$ Directive 2004/18/EC of the European Parliament and of the Council of 31 March 2004 on the coordination of procedures for the award of public works contracts, public supply contracts and public service contracts [2004] OJ L134/114. 
31(c) of Directive 2004/18/CE and Article 40(3)(b) of Directive 2004/17/EC 5 . Relying on these provisions, contracting authorities may award public contracts by negotiated procedure without prior publication of a contract notice when it is absolutely necessary due to extreme urgency caused by events which contracting authorities could not foresee and time limits for open, restricted and negotiated procedures with publication of a contract notice could not be complied with. At the same time, it is pointed out that the circumstances invoked to justify extreme urgency must not in any event be attributable to the contracting authority.

Article 67(1)(3) of the Public Procurement Act of 29 January $2004^{6}$ is proof that these regulations have been implemented into the Polish legal system. This Article was the basis for awarding a negotiated contract for continuation of construction of the Municipal Stadium in Wrocław during preparations for the 2012 European Football Championships. The procedure was necessary due to termination of the contract with the previous operators with immediate effect. On the basis of those events, the National Appeals Chamber (Krajowa Izba Odwolawcza, hereinafter referred to as the KIO) adopted resolution $\mathrm{KIO} / \mathrm{KD} 58 / 10$ on 6 August $2010^{7}$ in which it interpreted the grounds for negotiated procedure in cases of extreme urgency. This interpretation has put forward new concepts in comparison to the hitherto interpretations of the European judicature. The resolution's provisions should first be submitted to assessment on the basis of current interpretation of grounds for public procurement procedures specified in the content of the relevant directives as a negotiated procedure without publication of a contract notice, expressed in judgments of the Court of Justice of the European Union (Court of Justice) (see: Article 31 of Directive 2004/18/EC and Article 40 of Directive 2004/17/EC).

\section{CURRENT JUDICIAL DECISIONS OF THE COURT OF JUSTICE}

In adjudicating compliance of procedures applied in specific circumstances with European Union law, the Court of Justice has provided a number of interpretational directives. These directives have the form of general statements stressing the necessity of strict interpretation of the legal basis of awarding contracts under a negotiated procedure without publication of a contract notice and determination of specific premises for application of the procedure. As the legal regulation under discussion constitutes a derogation from fundamental public procurement principles, in particular protection of competition and transparency, circumstances justifying the

\footnotetext{
${ }^{5}$ Directive 2004/17/EC of the European Parliament and of the Council of 31 March 2004 coordinating the procurement procedures of entities operating in the water, energy, transport and postal services sectors [2004] OJ L134/1.

${ }^{6}$ Public Procurement Act 29 January 2004 (Journal of Laws 2010, no 113, item 759).

7 Resolution $\quad \mathrm{KIO} / \mathrm{KD} \quad 58 / 10$ of $6 \quad$ August 2010 $<$ www.uzp.gov.pl/cmsws/page/GetFile1.aspx?attid=2102> accessed 16 December 2012.
} 
derogation should be interpreted strictly and the burden of proving exceptional circumstances lies on the contracting authority ${ }^{8}$. At the same time, it is not possible to introduce additional grounds into the legal systems of member states which in practice would extend the scope of application of the negotiated procedure without publication of a contract notice, not to mention establishing other cases than those resulting from the directives, which would allow for awarding contracts under a special procedure ${ }^{9}$. At the same time the Court of Justice has introduced three fundamental conditions for the application of the negotiated procedure without publication of a contract notice by the contracting authority: 1) occurrence of an unforeseeable event, 2) particularly urgent nature of the case, which makes rendering the observance of time limits laid down by other procedures impossible, and 3) a causal link between the unforeseeable event and extreme urgency resulting therefrom ${ }^{10}$. It is worth adding that the unforeseeable event must not be attributed to the contracting authority.

It should be stressed that these judicial decisions do not refer to all of the prerequisites given above to an equal extent. In some judicial decisions the Court of Justice indicates explicitly that it is not referring to other prerequisites as it considers that one of them is unfulfilled ${ }^{11}$. The existence in a given case of urgent necessity rendering it impossible to award a contract within time limits provided in other, more competitive procedures is the type of case most frequently assessed in European Union judicature. Noncompliance with this requirement was adjudicated by the Court of Justice e.g. in reference to the facts analysed in the judgment in case no. C-24/91 ${ }^{12}$. The Court of Justice declared that awarding additional funding in January for erection and commissioning of new research and education facilities by one of Madrid's higher education institutions before the start of the new academic year (October) with an assumed 7.5-month investment delivery time could not be deemed as equivalent to extreme urgency in the awarding of a contract. In light of the public procurement procedure applicable to construction works at that time, ${ }^{13}$ it was held in this situation that it was possible to carry out proceedings following an accelerated limited procedure, which would offer a minimum total period for submission of applications for admission to tender and offers amounting to 22 days ${ }^{14}$. At the same time the Court declared that

\footnotetext{
${ }^{8}$ See Case C-57/94 Commission v Italy [1995] ECR I-1249, para 23; Case C-318/94 Commission v Germany [1996] ECR I-1949, para 13; Case C-385/02 Commission of the European Communities v Italian Republic [2004] ECR I-08121, para 19.

${ }^{9}$ Case C-84/03 Commission of the European Communities $v$ Kingdom of Spain [2005] ECR I-00139, para 49.

${ }^{10}$ See Case C-107/92 Commission of the European Communities v Italian Republic [1992] ECR I-4655, para 12; Case C-318/94 Commission v Germany (n 8) para 14; Case C-394/02 Commission of the European Communities v Hellenic Republic [2005] ECR I-04713, para 40 .

${ }^{11}$ Case C-107/92 Commission of the European Communities v Italian Republic (n 10), para 15; Case C-318/94 Commission v Germany (n 8), para 20.

12 Case C-24/91 Commission of the European Communities $v$ Kingdom of Spain [1992] ECR I-01989, paras 6,8,15.

13 See Article 15 of Council Directive 71/305/EEC of 26 July 1971 concerning the coordination of procedures for the award of public works contracts [1971] OJ L185/5. Now Article 38(8) of Directive 2004/18/EC.

${ }^{14}$ Case C-24/91 Commission of the European Communities $v$ Kingdom of Spain (n 12), para 4 .
} 
a potential increase in the number of students in the coming academic year could not be deemed as an unforeseeable circumstance, as this upward trend was observable earlier and should have been known to a higher education institution $^{15}$.

The condition of extreme urgency rendering the award of contracts impossible within the time limits provided for in other procedures was also considered in the judgment in Case C-107/92. The judgment indicated that the lapse of three months between the time when the contracting authority learnt of increased avalanche risk as presented in a geological report and the time when construction works were commenced may not be construed as extreme urgency. On the contrary, failure to start the works within that period proved that the contract award procedure could have been carried out under a different procedure, including in particular an accelerated restricted procedure $^{16}$.

In its assessment of Case C-385/02, the Court of Justice also did not hold that the premise of extreme urgency existed when the contracting authority, awarding a contract without a contract notice, referred to extreme urgency to complete construction works regarding flood safety. In this case it stemmed from stage-by-stage execution of the construction investment depending on available financial resources, with the process intended to last for years. As a result, it was found that no extreme urgency had occurred, and the need for awarding the contract arose out of the arrangements previously put into place ${ }^{17}$.

Similarly, in the judgment in Case C-126/03 ${ }^{18}$, the Court established that the premise of extreme urgency, rendering the observance of time-limits laid down by other procedures impossible, did not exist when the City of Munich took part as a contractor in proceedings conducted by another contracting authority, namely a company engaged in waste transport services. Being unable to fully execute the contract with regard to waste transport to a combustion plant in its own capacity, the city decided to make use of the potential of a an contractor in the form of an enterprise specializing in such operations. Nevertheless, that enterprise was selected without an open procedure. That was justified by extreme urgency rendering the observance of time-limits relevant to competitive procedures impossible, which was the result of the city's application for a contract that demanded confirmation of the contractors' compliance with the entity qualification requirements within the time-limit set by the contracting authority. In this case as well it was acknowledged that, taking into account the time-limit for tendering, it would have been possible for the City of Munich as holder of contracting authority

\footnotetext{
15 ibid, para 10.

${ }^{16}$ Case C-107/92 Commission of the European Communities v Italian Republic (n 10), para 8.

${ }^{17}$ C-385/02 Commission of the European Communities v Italian Republic (n 8), paras 25, 27-28.

${ }^{18}$ Case C-126/03 Commission of the European Communities v Federal Republic of Germany [2004] ECR I-11197.
} 
status ${ }^{19}$ to select the entity within the time-limit relevant to an accelerated procedure $^{20}$. However, in this case the Court of Justice did not consider the possibility of foreseeing situations like the one presented above.

In its ruling in Case C-318/94, the Court in turn focused on the premise of 'unforeseeable circumstance'. As it was stated in the judgment, the refusal to grant a permit required for the execution of a contract under the law of a Member State and within the time-limit set therein cannot be deemed to fall within this category of circumstance. In the facts of the case, the contracting authority justified awarding the contract under the negotiated procedure without publication of a contract notice on the grounds of an unforeseen - in its opinion - yet legally admissible refusal by a competent authority to grant a permit for an investment involving the deepening of a river bed. Several months after the refusal decision was handed down, a decision approving the deepening of the river bed was issued. That reduced the time for execution of the contract that the contracting authority intended to correlate with production dates of the shipyard located on the river. The deepening of the river was indispensable to enable timely receipt of a large ship which was at that time under construction at the shipyard. At the same time, it was emphasised that the shipyard was the largest employer in the region, with a strong impact on the region's overall economic condition, and the investment underway was important in maintaining the shipyard's presence on the market ${ }^{21}$. This is why the contracting authority's opinion referred to extreme urgency as the consequence of an unforeseen event. The Court did not acknowledge those arguments, stating that a legally admissible decision issued by a competent body within the set time-limit cannot be regarded as an unforeseen event even if it causes a delay in the prospect of executing the contract $^{22}$.

A situation very similar to the one presented above was assessed in the judgment in Case C-394/02. In this matter, the contracting authority, which was a Greek state-owned thermal-electricity generation plant, lodged an application for a decision on the assessment of the effects on the natural environment of an investment involving the installation of a system for the de-sulphuration, stabilisation, transport and deposit of solid waste produced by the plant. In late 1999, the competent authority gave its approval for that project, subject to the implementation of the investment within 12 months. With regard to the specified time-limit the contracting authority considered this to be a case of extreme urgency resulting from an unforeseen circumstance, and made the decision to award the contract under the negotiated procedure without publication of a contract notice ${ }^{23}$. Similarly to Case C-318/94, the Court considered the fact that an authority which must

\footnotetext{
${ }^{19}$ The Court of Justice declared that, according to the facts of the case the city was at the same time a contractor applying for awarding a contract by another entity, but it did not lose its status of a contracting authority as regards the activity of contractual entrustment of a subcontractor with performance of waste transport services for the benefit of the contracting authority (C-126/03 Commission of the European Communities $v$ Federal Republic of Germany (n 18), para 18).

20 ibid paras, 22-23.

${ }^{21}$ Case C-318/94 Commission v Germany (n 8), paras 2-5.

22 ibid, paras 17-18.

${ }^{23}$ Case C-394/02 Commission of the European Communities v Hellenic Republic (n 10), paras 6-8.
} 
approve an investment project may impose time-limits to be a foreseeable part of the procedure for approving that project ${ }^{24}$. Hence, in those circumstances it was impossible to accept the fulfilment of the conditions for using the extraordinary negotiated procedure for awarding contracts. The Court also added that the contract award procedure could have been launched in the course of project approval, which had started in $1997^{25}$.

The judgment in Case C-525/03 should also be mentioned. In this matter, the European Commission alleged that Italy had infringed the obligation to allow entrepreneurial freedom and provide services through an order issued by the Italian administrative authorities on the admissibility of purchasing equipment used for extinguishing seasonal fires under the negotiated procedure without publication of a contract notice.

However, since in this matter the Court found the actions of the Commission inadmissible for procedural reasons, it did not give its opinion as to the merits of the case ${ }^{26}$. Still, the premise of unforeseeability was considered in the opinion issued by the Advocate General in this matter. The opinion found that 'widespread outbreaks of forest fires may be reasons of extreme urgency giving rise to a need for the acquisition of fire-fighting services and equipment if they are not already sufficiently available. ${ }^{27}$ On the other hand, it stressed that outbreaks of forest fires are a regularly recurring event throughout southern Europe, thus they cannot be considered unforeseeable. Nevertheless, forest fires of exceptional intensity ${ }^{28}$ caused by exceptional weather conditions should be considered unforeseeable.

In summary, it should be stated that the case law of the Court of Justice to date, including interpretations of the provisions of directives on the legal foundations for the negotiated procedure without publication of a contract notice in extreme urgency, has been focused on assessing the possibility to conduct the proceedings in a particular case under a different (competitive) procedure and on the foreseeability of particular events. Yet, as it is reasonably stated in the opinions of scholars on public economic law, the contract award procedure under discussion applies to cases where 'the performance of a consideration does not permit delay and it is in the public interest ${ }^{29}$. The premise of the necessity to protect "the public interest" in cases of an urgent and unforeseeable threat to public order stems from the very character of the provision of Article 31(3)(c) of Directive 2004/18/EC and Article 40(3)(b) of Directive 2004/17/EC. The existing standards that allow exceptions from respecting internal market freedoms can only be

\footnotetext{
24 ibid, para 43.

25 ibid, para 44.

${ }^{26}$ Case C-525/03 Commission of the European Communities v Italian Republic [2005] ECR I-09405, paras 13-17.

27 ibid, Opinion of AG Jacobs, para 61.

28 ibid, paras 63-64, 66-67.

${ }^{29}$ M Motyka-Mojkowski, 'Obowiązek prounijnej wykładni Prawa zamówień publicznych na przykładzie uchwały KIO w sprawie zasadności udzielenia zamówienia z wolnej ręki’ (2011) 15 Monitor Prawniczy 808. See also A Sołtysińska, Europejskie prawo zamówień publicznych (Zakamycze 2006) 259.
} 
justified by an overriding public interest ${ }^{30}$. The requirement of immediate execution of the contract with regard to contracting authorities that are categorised as State, regional or local authorities, or bodies governed by public law (Article 1(9) of Directive 2004/18/EC and Article 2(1)(a) of Directive 2004/17/EC) arises due to the obligation to protect the public interest listed in the catalogue of public tasks of those contracting authorities ${ }^{31}$. Nevertheless, EU case law does not offer many interpretative tips on the forms of public interest that could be taken into account when applying the non-competitive negotiated procedure without publication of a contract notice. This issue, together with other matters not yet fully considered in the Court's case law such as the foreseeability of events consisting in nonperformance or improper performance of procurement contracts, have become the subject of consideration in the aforementioned resolution by the National Appeal Chamber (KIO). The approval of the views presented therein on the EU level may result in the adoption of new (additional) interpretative directives on the use of special procedures for the award of public contracts under discussion here.

\section{KIO RESOLUTION/KD 58/10}

As has been mentioned, the equivalent of the negotiated procedure without publication of a contract notice in the Polish legal regime is the single-source procurement procedure, and the principles of its application in case of extreme urgency are set out in Article 67(1)(3) of the Polish Public Procurement Act. Under this provision, the contracting authority may award a contract by single-source procurement procedure if - due to an exceptional situation not resulting from events brought about by the contracting authority that it could not have foreseen - there is a need for prompt execution of the contract and the time limits specified for other procedures may not be observed.

Undoubtedly, analysis of the interpretation of this provision provided by KIO resolution/KD 58/10 should start with a presentation of the facts with regard to which it was undertaken. After a restricted tendering procedure was conducted in April 2009, the contract for the construction of the Wrockaw Municipal Stadium was awarded to enterprises making up a Polish-Greek consortium. On 30 December 2009, the City of Wrocław and the company Wrocław 2012 - the contracting authorities which jointly conducted the procedure - terminated with immediate effect the contract concluded with the previous contractors due to a 90-day delay in the performance of construction works. In the contracting authorities' opinion, the delay was constantly increasing over the course of execution of the contract. On 16 January 2010, a contract to continue construction of the stadium was concluded with a German enterprise whose offer in the previous proceedings had been classified in second place. The contract was signed under the single-source procurement procedure in accordance with Article 67 (1)(3) of the Polish

\footnotetext{
${ }^{30}$ M Szydło, Swobody rynku wewnętrznego a reguly konkurencji. Między konwergencja a dywergencja (TNOiK Dom Organizatora Toruń 2006) 67.

${ }^{31}$ See G Wicik, P Wiśniewski, Prawo zamówień publicznych. Komentarz (C.H. Beck 2012) 379.
} 
Public Procurement Act. In the contract, the entrepreneur undertook to put the construction into operation within 17.5 months, i.e. by 30 June 2011, which was the deadline required by UEFA. In the grounds for awarding the contract in the aforementioned proceedings, the contracting authorities also referred to the risk of being deprived of the rights of a championships host city due to the failure to put the stadium into operation within the set time limit, and to the potential material damage arising therefrom, estimated at PLN 1.6 billion.

These circumstances were assessed during an ad hoc audit carried out by the President of the Public Procurement Office ('PPO') ${ }^{32}$. As was emphasised in the post-audit report, the award of the contract under the single-source procurement procedure set out in Article 67 (1)(3) requires the occurrence of all of the following circumstances: 1) an exceptional situation, 2) recognition that the reasons for the occurrence of this situation are not attributable to the contracting authority, 3) the contracting authority's inability to foresee this situation, 4) a need for the immediate performance of the contract and 5) the impossibility of complying with the time limits specified for other contract award procedures ${ }^{33}$. After the audit it was established that not all of the circumstances required for this special procedure had occurred. Firstly, the contracting authorities' failure to prove the occurrence of extreme urgency was indicated. The President of the PPO cited the fact of the contracting authorities' termination of the contract with immediate effect due to the improper performance thereof (delays jeopardising the timely performance of the contract). This circumstance was deemed foreseeable, and the fact was stressed that an improper performance of contractual obligations does occur in business relations, without exceeding standard commercial conditions. The necessity to terminate contracts in such situations is the consequence of economic risk foreseeable in contracts in the form of relevant clauses providing for the termination thereof without a specified date. This particularly concerns complex investments carried out under tight deadlines. For this reason, non-compliance with the time limits for performance of complex contracts for construction works is a circumstance that must be reckoned with by the contracting authority. Moreover, it was emphasised that since the termination of the contract was a decision made by the contracting authorities themselves, it could not have been considered as an unforeseeable circumstance.

The President of the PPO also referred to the premise of an inability to conduct the proceedings under a different procedure due to the necessity of immediate performance of the contract. According to the post-audit records, the restricted procedure which - pursuant to Article 49 and 52 of the Polish Public Procurement Act - allows for a reduction of the time limit for submission of requests to participate in a procedure to 10 days, as well as the time limit for submission of tenders after the assessment of requests to participate in a procedure, could have been used in this case. The President of

\footnotetext{
${ }^{32}$ Control on the basis of Article 165-168a of the Public Procurement Law.

${ }^{33}$ Information on short-term control as regards legality of selection of a negotiated contract awarding procedure dated 9.07.2010, UZP/DKD/KSR/2299/13638/10 <www.uzp.gov.pl/cmsws/page/?PDF;1146> accessed 16 December 2012.
} 
the PPO gave a negative opinion as to the contracting authorities' contention that the time limits for awarding contracts could not have been observed under other procedures due to the material probability of the contractors' recourse to legal remedies. The post-audit report contained the opinion that this prediction was purely hypothetical, and the contractors' potential exercise of their rights could not be considered to justify the contracting authority's use of non-competitive contract award procedures. Furthermore, it was emphasised that, in exceptional circumstances, the provisions regarding legal remedies provide for the possibility to obtain a permit from the National Appeal Chamber for concluding a contract before the appeal has been settled, while a resultant complaint lodged with a Regional Court shall not have suspensive effect with regard to the conclusion of the contract (see Article 183 (1-2) of the Polish Public Procurement Act). The contracting authorities formulated objections to the conclusions reached during the ad hoc audit, which were settled in their favour by resolution $\mathrm{KIO} / \mathrm{KD} 58 / 10$.

Assessment of the contents of this Resolution will firstly be focused on the approach to the premise of an exceptional situation, different from the one presented in the post-audit report. In accordance with the PPO President's post-audit report, that premise was identified in principle with the contracting authorities' decision, which was the consequence of the delayed performance of works falling within standard and foreseeable economic conditions. However, the KIO primarily referred to the fact of the contracting authorities' participation in organising the 2012 European Football Championships and its obligations towards UEFA arising therefrom. As it was stressed, the grounds for invoking this exceptional situation was the risk of losing the right to organise the Championships as a host city and consequent financial losses, as well as lost profits estimated by the contracting authorities at PLN 1.6 billion. The resolution presented the concept of an exceptional situation in a broader sense, including in its scope the fact of material delay attributable to the contractor ${ }^{34}$, and ultimately the very decision of the contracting authorities to terminate the contract as the effect of this situation.

When considering the termination of a contract in consequence of a significant delay in the performance of construction works seriously compromising the timely execution of the contract, the KIO held that the circumstance of such a delay was unforeseeable. In the Resolution it was simply stated that 'the termination of any contract with the existing contractor regardless of the reasons for such an action (...) is an (...) absolutely extraordinary situation'. It was emphasised that when concluding a contract in good faith, the parties do not envision the necessity of withdrawing from it. Taking this risk into account in the contents of a contract does not mean predicting the occurrence of the reasons for terminating the contract in the

\footnotetext{
${ }^{34} \mathrm{KIO}$ found it possible to adopt an assumption of a delay as a circumstance attributable to the contractor on the basis of documents presented by contracting authorities. Such a finding is specific to the proceedings adopted by KIO which aim at issuing opinions on reservations of the contracting authority concerning results of post-control audits issued by the President of the Public Procurement Office. The proceedings are not contradictory as they are not conducted as part of proceedings to take evidence, but they consist in assessing audit proceedings files of the President of PPO and adopting a position as regards reservations of the contracting authorities (P Granecki, Prawo zamówien publicznych. Komentarz (C.H. Beck 2012) 701). The opinion issued by the KIO in such cases is binding for the contracting authority (Article 167(4) of the Public Procurement Act).
} 
future. According to the KIO, 'anticipating the termination of a public procurement contract attributable to the contractor and assuming that it falls within 'standard business relations' firstly contradicts the aim and sense of awarding contracts, and secondly questions the reliability of the contractors' review at the stage of their compliance assessment.'

Consequently, it should be recognised that in light of the discussed resolution the exceptional situation that could not have been foreseen by the contracting party was the significant and constantly growing delay in the performance of the contract (the scale of the delay). Still, the very decision to terminate the contract should only be perceived as the effect of this unforeseeable circumstance. In assessing the exceptionality of the situation, one cannot disregard the importance of the investment for compliance with the requirements imposed on the organiser of such a significant event as the 2012 European Football Championships, and therefore include in deliberations the sanction of being deprived of the right to organise the championships due to the failure of the stadium investment. This risk - if it were to materialise as a consequence of the failure to put the stadium into operation within the set time limit - could pose not only the threat of considerable financial losses but would also test the viability of many other activities undertaken by the contracting authorities to prepare for the role of host city.

The meaning of this interpretation results from recognition of the investment objectives - so crucial to economic and cultural development as well as the promotion of the city (local community) - as a factor that may justify the exceptional character of the situation within the meaning of Article 67(1)(3) of the Polish Public Procurement Act. From the perspective of the catalogue of values (goods) anchored in EU regulations and case law, the protection of which is given priority over the goal of realization of the internal market if they clash with the basic economic freedoms, such justification can raise considerable doubts. Examples of those values include public security and public order, the protection of life and health of people and animals, the protection of national cultural goods of artistic, historical or archaeological value, or the protection of industrial and commercial property (see for example Articles 36 and 52 TFEU). The so-called imperative requirements, developed in the case law of the Court of Justice, provide for the possibility of derogation from the binding force of regulations on internal market freedoms where such is indispensable for the protection of values including the protection of consumers, the protection of fairness of trade transactions (fairness of competition), ensuring efficient tax control, supporting media pluralism and maintenance of a balanced social insurance system ${ }^{35}$. These examples do not, however, permit the formulation of categorical conclusions as to the possibility of recognising considerations of the protection of the public interest identified with socio-economic development as justifications for restricting internal market freedoms in the public procurement market.

Evaluation of this issue also demands reference to the contents of legal regulations governing the award of contracts introduced into the EU legal

\footnotetext{
${ }^{35}$ Szydło (n 30) 471-496 judicial decisions provided therein.
} 
order in the period following that of the Court of Justice case law mentioned above. It must be noted that the contents of Directive 2007/66/EC of the European Parliament and of the Council of 11 December 2007 amending Council Directives $89 / 665 / \mathrm{EEC}^{36}$ and $92 / 13 / \mathrm{EEC}^{37}$ with regard to improving the effectiveness of review procedures concerning the award of public contracts $^{38}$, enacted new regulations which, in particular situations, allowed the national deciding authorities (review bodies) in cases regarding the awarding of contracts, to refrain from imposing the otherwise obligatory sanction of contract ineffectiveness with a view to protecting an important public interest, including economic interest in exceptional instances. Pursuant to Article 1(1) and Article 2(1) adding to Directives 89/665/EEC and 92/13/EEC the new provisions of Article 2d(3), the Member States implementing the Directives may provide that the review body may not consider a contract ineffective even though it has been awarded illegally if the review body finds, after having examined all relevant aspects, that overriding concerns relating to the general interest require that the effects of the contract should be maintained. At the same time, it is indicated that economic interests in the effectiveness of a contract may only be considered as overriding reasons if in exceptional circumstances ineffectiveness would lead to disproportionate consequences. However, economic interests directly linked to the contract and constituting costs stemming from such circumstances as delay in the execution of the contract, the launching of a new procurement procedure, the change of the economic operator performing the contract and the costs of legal obligations resulting from ineffectiveness should not constitute overriding reasons. The implementation of those provisions of the Directive into the laws of Poland is manifested in Article 192(3)(2)(c) in conjunction with Article 192(5) of the Polish Public Procurement Act. In such cases, the sanction of contract ineffectiveness may be replaced with a financial penalty or reduction of the contract duration. Thus, the EU legislator has established the category of a material public interest justifying derogations from imposing the sanction of ineffectiveness of a public procurement contract, also with reference to the unspecified concept of economic interest; this concept, however, excludes economic interest directly linked to the contract, including the costs of delay. This interpretation must be regarded as highly questionable when the implementation of a particular public contract is significant not only for the contracting authority (the organisational entity awarding the contract) but also for a particular community impacted to a large extent and in many dimensions of its functioning by the actions of the contracting authority.

\footnotetext{
${ }^{36}$ Council Directive 89/665/EEC of 21 December 1989 on the coordination of the laws, regulations and administrative provisions relating to the application of review procedures to the award of public supply and public works contracts [1989] OJ L 395/33.

${ }^{37}$ Council Directive 92/13/EEC of 25 February 1992 coordinating the laws, regulations and administrative provisions relating to the application of Community rules on the procurement procedures of entities operating in the water, energy, transport and telecommunications sectors [1992] OJ L 76/14.

${ }^{38}$ Directive 2007/66/EC of the European Parliament and of the Council of 11 December 2007 amending Council Directives 89/665/EEC and 92/13/EEC with regard to improving the effectiveness of review procedures concerning the award of public contracts [2007] OJ L $335 / 31$.
} 
Efforts to resolve this dilemma should firstly focus on the fact that legal notions concerning legal remedies for securing the contracting authorities' interests cannot be automatically transferred to the sphere of principles for the use of special contract award procedures, including singlesource procurement in exceptional situations. Nevertheless, the regulation presented above clearly demonstrates that the EU legislator acknowledges material economic interests as grounds for justifying derogation from imposing the sanction of contract ineffectiveness associated with the most far-reaching infringements of public procurement law (see Article $2 \mathrm{~d}(1)$ of Directives 89/665/EEC, 92/13/EEC and Article 146(1) of the Polish Public Procurement Act). This allows the conclusion that a public interest of this kind - due to the disproportionate consequences of its violation - can also justify the exceptionality of a situation in which the contracting authority uses the single-source procurement procedure. It is worth noting that in the circumstances addressed by the KIO Resolution under discussion, not only was the direct economic interest of the contracting authorities themselves placed in jeopardy (organisational entities conducting the contract award procedure), but the much broader socio-economic interest of the local community was at risk because of the delays. To some degree, this community can even be identified with the formally-defined contracting authority itself, i.e. a local self-government entity which is a legal person whose personal substratum is made up of the inhabitants of the entity's territory ${ }^{39}$. Had UEFA imposed the sanction of revoking the host city's rights, that would have undoubtedly resulted in the loss of many considerable opportunities for the developing local community across a broad functional spectrum, not only connected with the development of public utilities but also in the areas of popularising sports and encouraging physical fitness, as well as tourism and business promotion. In these circumstances, the construction of the stadium and other related investments aimed at the proper fulfilment of the obligations of the host city for a sports event so popular all over the world cannot be perceived independently of the numerous public tasks of the local selfgovernment entity where they are undertaken and thus contribute to the satisfaction of the collective needs of a self-government community (see Article $7(1)(2,10,18)$ of the Polish Act on Local Self-Government). A passage from the opinion issued by Advocate General Elmer, formulated for the purposes of resolving Case C-318/94 presented above, is worth quoting here. This opinion emphasises that the intention of the state to support entrepreneurs' activities by way of adequate infrastructural investments cannot be perceived as extreme urgency for the awarding of a contract if the delays in their execution impede or preclude the growth of particular entrepreneurs. Nevertheless, such a necessity can be acknowledged if public investments are indispensable for the further functioning of entrepreneurs of great importance to the region's economy and job market ${ }^{40}$.

\footnotetext{
${ }^{39}$ Local self-government Act 8 March 1990 Article 1 (Journal of Laws 2001, no. 142, item $1591)$.

${ }^{40} \mathrm{C}-318 / 94$ (n 10), Opinion of AG Elmer, paras 18-19.
} 
To summarize this part of our reflections, the admissibility of substantiating an exceptional situation within the meaning of Article 67(1)(3) of the Polish Procurement Act on the grounds of protecting socio-economic interests in the event that their violation would lead to disproportionate consequences should be supported. It needs to be emphasised that this would encompass results affecting not only the organisational entity directly conducting the contract award procedure, but above all a particular community (local or broader), leading for example to its missing a material opportunity for development ${ }^{41}$. It should be recognised that the KIO resolution under review properly assesses the reason for the occurrence of the exceptional situation, referring to an excessive and increasing delay in the performance of the contract attributable to the contractor. The interpretation which identified the premise of an exceptional situation with the contracting authorities' decision to terminate the contract without a specified time limit and assuming the foreseeability of such circumstances due to the fact that such termination is the responsibility of the contracting institution should be considered incorrect. Such a decision is only the consequence of a situation whose occurrence is attributable to the contractor. It is worth noting that in his report on the ad hoc audit, the President of the Polish Public Procurement Office also attributed the fact of unforeseeability to the very scale of the delay. Identifying an exceptional situation with the contracting institution's decision to terminate a contract, and not the actual cause which provides a legal basis for such a decision in the given situation, leads to the conclusion that the discussed contract award procedure will not be applicable in any case of contract termination by the contracting authority. On the other hand, the interpretation which completely disregards non-performance or improper performance of the obligations by contractors as unexpected situations just because the consequent termination or withdrawal from the contract results from the contracting authority exercising its particular rights could be alleged to be excessively rigorous and even arbitrary to an extent. The presented arguments allow for a reference to the possibility of extending the existing interpretation of the reviewed provisions by exceptional situations (random events) beyond natural disasters, (floods, fires, avalanches), industrial emergencies, transport catastrophes, industrial accidents or the threat of their occurrence $^{42}$. It should also be recognised that, with regard to the situations of non-performance or improper performance of obligations, foreseeable and unforeseeable events should be differentiated, while the latter could also be combined with the scale and potential consequences of irregularities in the performance of obligations. Such events also differ in quality from circumstances not recognised by the case law of the Court of Justice as providing grounds for the use of the negotiated procedure without publication of a contract notice, where public bodies exercise their competencies in a manner unexpected by contracting authorities. While the former are unlawful, the latter constitute actions by public bodies exercising their rights.

Moreover, it should also be emphasised that resolution $\mathrm{KIO} / \mathrm{KD} 58 / 10$ also provides a material interpretation of the premise of 'the necessity for

\footnotetext{
${ }^{41}$ On the contrary, M. Motyka-Mojkowski excludes the possibility of protecting commercial interests (financial) on the basis of the premises provided for in Article 67(1) (3) of the Public Procurement Act, (n 29) 810.

${ }^{42}$ See Granecki (n 34) 701, Sołtysińska (n 29) 257, Wicik, Wiśniewski (n 31) 379.
} 
immediate execution' of the contract as the consequence of the occurrence of an exceptional and unforeseeable situation. As stressed in the resolution, it cannot be 'identified with immediate commencement and immediate completion of the performance of the contract that would have to take place over a short period of time'. Hence, the thesis that only 'short-term' contracts can be awarded under the presented procedure should be held incorrect ${ }^{43}$. In this context, it is also worth noting that KIO approved of the contracting authorities' position on the possibility of considering the contractors' potential recourse to legal remedies as having an impact on the establishment of whether the premise of inability to observe the time limits specified for other contract award procedures had occurred or not. Taking those aspects into account, KIO acknowledged the existence of a necessity for immediate performance of the contract at the time of awarding the contract to continue the construction of the stadium.

\section{CONCLUSION}

The effort to assess the discussed KIO resolution cannot disregard the fact that, pursuant to Article 258 TFEU, the European Commission initiated an investigation on Poland's infringement of Treaty obligations regarding the procedure for awarding the contract to continue construction of the Municipal Stadium in Wrocław ${ }^{44}$. These proceedings have not yet been concluded ${ }^{45}$. The basis for acknowledging the contracting authorities' procedure as correct in that situation would be approval by the Commission or the Court itself of the interpretative assumptions accepted by KIO, amongst others consisting in the exceptional admissibility of recognising extreme urgency for performance of the contract due to the need for protecting economic interests, the infringement of which could result in disproportionate consequences for the community impacted by the contracting authorities' actions; it should also consist in recognising the fact that while the improper performance of the obligation to carry out construction works caused by a delay is an element that can be acknowledged as foreseeable in a general sense, in these particular circumstances the unforeseeability of the scale of the delay, jeopardising the general performance of the contract, or objectively unforeseeable reasons for the very delay, should be taken into consideration. In such circumstances this

\footnotetext{
${ }^{43}$ In this respect KIO departed from its view expressed in resolution $\mathrm{KIO} / \mathrm{KD} 21 / 09$ of 13.08.2009. The resolution provided that "a crucial characteristic of a contract awarded on the basis of the premise provided in Art. 67(1)(3) of the Public Procurement Act is the immediacy of performance, quick reaction and short period of the contract, the main aim of which is to eliminate imminent effects of an event which could not be foreseen. Awarding a contract for the period of one year does not fulfil the premise specified in the provision".

${ }^{44}$ On the basis of media reports: < http://www.gazetawroclawska.pl/artykul/480327,brukselaoskarzy-polske-za-budowe-wroclawskiego-stadionu,id,t.html $>$,

$<$ http://www.polskieradio.pl/5/3/Artykul/494384,Bruksela-oskarza-Polske-Stadion-bezprzetargu $>$ accessed 16 December 2012.

45 The procedure is still at an initial stage as Poland has not received yet a justified opinion on failure to comply with treaty obligations as a Member State.
} 
would in turn result in acceptance of this element as an exceptional situation, rather than the resultant decision of the contracting authority to terminate the contract $^{46}$. At least to some extent, the presented interpretative assumptions can be acknowledged as a novelty, or an element closing gaps in the previous interpretation at the EU level of the legal grounds for using the negotiated procedure without publication of a contract notice. If the Commission or the Court were to accept the interpretative assumptions presented here, it would provide an extremely interesting instance of a national case law's impact on the functional practices of EU bodies.

\footnotetext{
${ }^{46}$ Press announcement of the European Commission of 08.10.2009 (IP/09/1470) on filing a justified opinion on breaching of Art. 226 of the Treaty of the European Community (currently TFEU) with the Republic of Slovakia, 'Public procurement: Commission requests Slovakia to review legal services contracts for motorway construction project' $<$ http://europa.eu/rapid/press-release_IP-09-1470_en.htm\#PR_metaPressRelease_bottom> accessed 16 December 2012. The procedure concerning failure to comply with obligations of a Member State was completed with the filing of a complaint by the Commission to the Court of Justice (case C-531/10), however, judgment was not issued as the compliant was withdrawn by the Commission $<$ http://curia.europa.eu/juris/document/document.jsf?text $=\&$ docid $=81924 \&$ pageIndex $=0 \& d$ oclang=FR\&mode $=$ lst\&dir $=\&$ occ $=$ first $\&$ part $=1 \&$ cid $=107266>$ accessed 16 December 2012.
} 